\title{
Inisiasi Implementasi Zenius sebagai Aplikasi Pembelajaran Online di SD Muhammadiyah Wonorejo
}

\author{
Fuad Anwar*, Soeparmi, Cari, Riyatun, Suharyana, Mohtar Yunianto, Darmanto \\ Program Studi Fisika, Fakultas MIPA, Universitas Sebelas Maret Surakarta \\ *fanwar@staff.uns.ac.id
}

\begin{abstract}
Abstrak
Telah dilakukan inisiasi implementasi zenius yang merupakan aplikasi pembelajaran online di SD Muhammadiyah Wonorejo yang diikuti 17 Guru. Dalam kegiatan tersebut dibagi menjadi 2 tahap, tahap pengenalan Aplikasi berbasis Desktop untuk menu pengunjung, Guru, Murid dan Orang tua. Untuk menu Guru dilatih untuk mengelola kelas, mengunggah materi pembelajaran, membuat soal, melakukan penilaian siswa serta melakukan pelaporan nilai ke orang tua. Tahap berikutnya adalah pengenalan Aplikasi berbasis Android, di latihkan untuk menu Murid, berisi lihat materi pembelajaran, presensi, mengerjakan soal ujian dan mengetahui hasil ujian. Sebelum dilakukan pelatihan sebagian besar tidak memahami aplikasi pembelajaran online, setelah dilakukan pelatihan semua peserta memahami dan akan mengimplementasikan dalam proses pembelajaran di kelas.
\end{abstract}

Kata kunci-zenius, pembelajaran online, aplikasi, android, pandemi

\section{Pendahuluan}

Pandemi COVID-19 memberikan dampak pada banyak pihak, dimana kondisi ini sudah merambah pada dunia pendidikan, pemerintah pusat sampai pada tingkat daerah memberikan kebijakan mengganti system pembelajaran dari system luring menjadi system daring menggunakan pembelajaran online ( Anugraha, 2020). Hal ini dilakukan sebagai upaya mencegah meluasnya penularan COVID-19. Kebijakan lockdown atau karantina dilakukan sebagai upaya mengurangi interaksi banyak orang yang dapat memberi akses pada penyebaran virus corona. Kebijakan yang diambil oleh banyak negara termasuk Indonesia dengan meliburkan seluruh aktivitas pendidikan, membuat pemerintah dan lembaga terkait harus menghadirkan alternatif proses pendidikan bagi peserta didik maupun mahasiswa yang tidak bisa melaksanakan proses pendidikan pada lembaga pendidikan. Hal ini didukung oleh Surat Edaran Nomor 4 Tahun 2020 tentang Pelaksanaan Kebijakan Pendidikan Dalam Masa Darurat Penyebaran Coronavirus Disease (Covid-19) yang ditandatangani oleh Menteri Pendidikan dan Kebudayaan Nadiem Makarim pada tanggal 24 Maret 2020. Prinsip yang diterapkan dalam kebijakan masa pandemi COVID-19 adalah "kesehatan dan keselamatan peserta didik, pendidik, tenaga kependidikan, keluarga dan masyarakat merupakan prioritas utama dalam menetapkan kebijakan pembelajaran" ( Kemendikbud, 2020).

Sekolah Dasar merupakan salah satu jenjang pendidikan yang merasakan dampak dari pandemi COVID-19 . Sudah sejak awal pandemi Sekolah dan juga pihak sekolah mulai mengubah strategi pembelajaran yang awalnya adalah tatap muka dengan mengubah menjadi pembelajaran non-tatap muka atau ada yang menyebut pembelajaran online dan juga pembelajaran Jarak Jauh ( Santoso, 2020). Berbagai model pembelajaran yang dapat digunakan guru untuk membantu siswa belajar di rumah. Pemerintah menyediakan berbagai aplikasi pembelajaran yang dapat diakses dan digunakan oleh guru dan siswa ( Astini, 2020). Media pembejaran online atau sering disebut dengan elearning merupakan media penunjang pendidikan dan bukan sebagai media pengganti Pendidikan, akan tetapi banyak kendala yang dihadapi ( Hadisi dan Muna, 2015).

Hal tersebut di alami juga oleh Guru dan siswa di SD Muhammadiyah Wonorejo, SD tersebut berada di desa Wonorejo, Kecamatan Polokarto, Kabupaten Sukoharjo, yang memiliki 17 Guru dan 235 siswa. Pada masa pandemi ini pembelajaran dilakukan dengan online melalui media whatsapp, penugasan dengan pengambilan ringkasan serta soal dan dikumpulkan pada waktu tertentu, hal ini memberikan efek bosan dan tidak menyenangkan 
bagi siswa dan Guru juga dituntut aktif disekolah untuk menyiapkan berkas-berkasnya. Dikarenakan pandemi ini belum dapat ditentukan kapan berakhirnya dan pembelajaran secara full luring juga belum di tentukan maka perlu upaya untuk tetap menyedikan pola pembelajaran online yang efektif, menyenangkan, murah dan mudah.

Sebuah Platform Pendidikan berbasis teknologi Zenius, telah memiliki lebih dari 80 ribu video pembelajaran gratis dengan format whiteboard sehingga kuota internet paling hemat, adanya interaksi antara Guru dan Murid, adanya fasilitas live teaching dengan fitur live chat, adanya fitur membuat dan mengirimkan rencana belajar harian ke akun siswa dan orang tua sehingga orang tua juga dapat memantau sehingga kemauan anak menjadi lebih terstruktur ( Zenius 2020). Aplikasi ini juga masuk dalam aplikasi Kuota Belajar dari Kemendikbud sehingga tidak mengkhawatirkan dalam menyediaan kuota ( infokomputer, 2020). Dalam versi mobile ada dalam google play menjadi aplikasi Nomer 1 untuk pembelajaran online. Solusi Atas Keterbatasan Akses bagi sekolah yang kesulitan akses internet adalah dengan menyediakan materi berbentuk file PDF secara gratis.

\section{Metode Pelaksanaan}

Dalam rangka memberikan solusi bagi kondisi yang dialami oleh pihak mitra maka metode yang digunakan dalam kegiatan ini adalah berupa pelatihan, Adapun tahapan-tahapan yang dilakukan adalah sebagai berikut :

1. Pelaksanaan aktivasi dan instalasi Aplikasi Zenius Aktivasi dan instalasi dilakukan dengan 2 cara, yaitu :

a. Melalui web browser di computer menggunakan alamat email dan no handphone,

b. Melalui handphone yang terlebih dahulu di instal aplikasi Zenius yang ada di playstore.

2. Pelaksanaan Pelatihan pemanfaatan zenius.

Langkah dalam pelatihan dilakukan dalam beberapa tahapan.

a. Melengkapi identitas terkait status yang semua ( Siswa, Guru, Orang tua atau umum ) serta jenjang Pendidikan.

b. Optimalisasi pemanfaatan Zenius dengan mengeksplorasi semua menu yang ada di aplikasi, baika materi, contoh soal ujian maupun video interaktif.

c. Pelatihan pemanfaatan fitur dalam Aplikasi melalui guru.zenius.com, fitur tersebut diantaranya adalah buat kelas, mengunggah materi, Menyusun soal, membagikan penilaian dan evaluasi penilaian

d. Pelatihan berkomunikasi dengan siswa dengan mengundang siswa untuk joint di aplikasi melalui API yang terkoneksi dengan whatsApp

e. Penggunaan aplikasi melalui Handphone android yang telah dilakukan instalasi dan aktivasi.

f. Ujicoba untuk implementasi aplikasi antara Guru dan Siswa.

\section{Hasil Dan Pembahasan}

Sebelum dilaksanakan kegiatan pelatihan terlebih dahulu dibagikan angket kepada peserta untuk mengetahui sejauh mana pemahaman awal terhadap aplikasi pembelajaran online, dari angket yang disebarkan diperoleh hasil sebagai mana tersaji pada Tabel 1.

Informasi yang diperoleh Tabel 1 bahwa semua peserta sudah menggunakan media komunikasi virtual dimana 76 $\%$ menggunakan Whatsapp sebagai media komunikasi dengan siswa, artinya sebagian besar berkomunikasi dengan siswa menggunakan text atau hanya sekitar $24 \%$ menggunakan media berbasis video, baik zoom meeting, google meet, Video call maupun Microsoft team.

Sedangkan yang sudah menggunakan aplikasi pembelajaran online baru sebesar $29 \%$, dimana sebagian besar menggunakan google classroom yaitu $24 \%$, melihat hal ini maka kegiatan berupa pengenalan aplikasi media pembelajaran online sangat penting untuk membuat cakrawala Guru berkaitan dengan media yang dapat digunakan sebagai alternatif dalam proses pembelajaran terutama dalam system daring.

Langkah awal yang dilakukan adalah mengenalkan aplikasi pembelajaran zenius, yaitu dengan melakukan registrasi dan konfigurasi profil untuk semua Guru melalui laman web zenius.net seperti pada Gambar 1. 
Tabel 1. Angket pra pelaksanaan pelatihan

\begin{tabular}{rlc}
\hline No & \multicolumn{1}{c}{ Uraian } & Prosentase \\
\hline 1 & Menggunakan Media komunikasi virtual & $100 \%$ \\
2 & Jenis Media komunikasi & \\
& $\bullet \quad$ Zoom meeting & $6 \%$ \\
& $\bullet \quad$ Google meet & $6 \%$ \\
& - WhatsApp & $76 \%$ \\
& - Video call & $6 \%$ \\
& - Microsoft team & $6 \%$ \\
3 & Menggunakan Aplikasi Pembelajaran online & $29 \%$ \\
4 & Jenis Aplikasi pembelajaran & \\
& - Google classroom & $24 \%$ \\
& - Ruang Guru & $6 \%$ \\
\hline
\end{tabular}
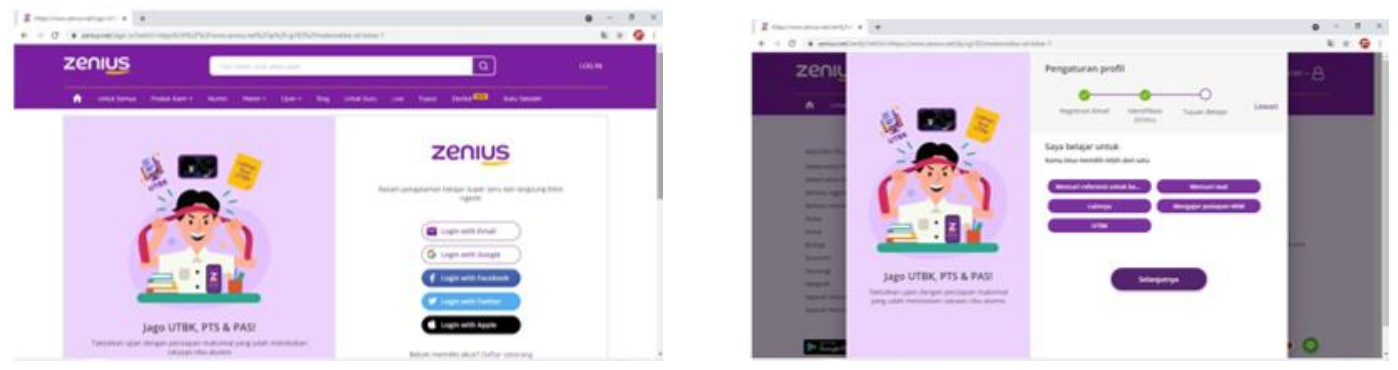

Gambar 1. Tampilan halaman login dan proses pengaturan profil

Apabila sudah terdaftar dan sudah melakukan konfigurasi profil, langkah berikutnya adalah mengelola di laman guru.zenius.com dengan terlebih dahulu login dan mengisi profil secara lengkap seperti pada Gambar 2.
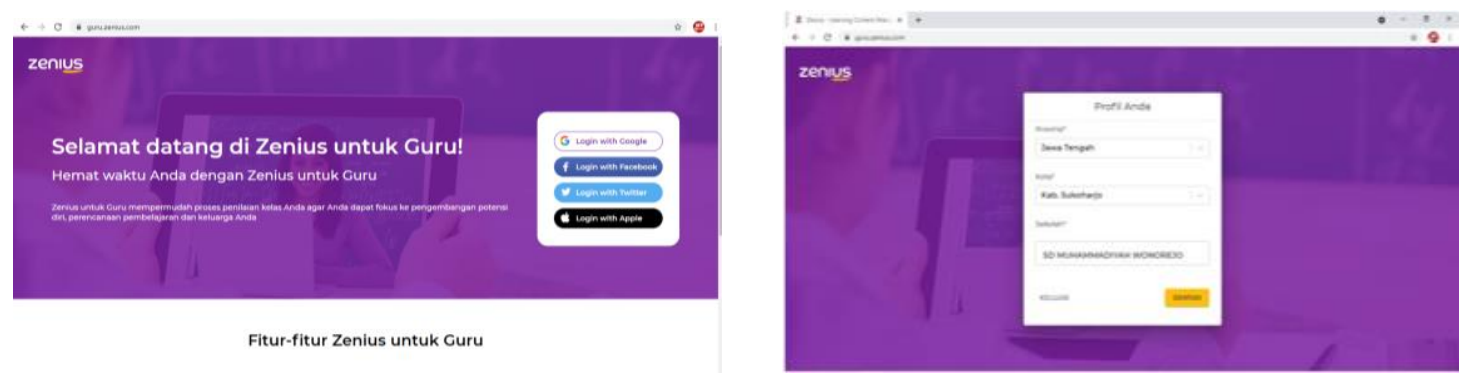

Gambar 2. Tampilan untuk proses login dan konfigurasi Guru di guru.zenius.com

Menu yang berada pada laman Guru setelah login diantaranaya adalah menu untuk membuat kelas, mengunggah materi pelajaran, mencari materi pembelajaran, mengundang siswa untuk gabung di kelas, mencari paket soal, menu untuk membuat penilaian dengan terlebih dahulu membuat soal, membagikan ke siswa melalui link di whatsapp dan merekap nilai dari soal yang dikerjakan oleh siswa. 


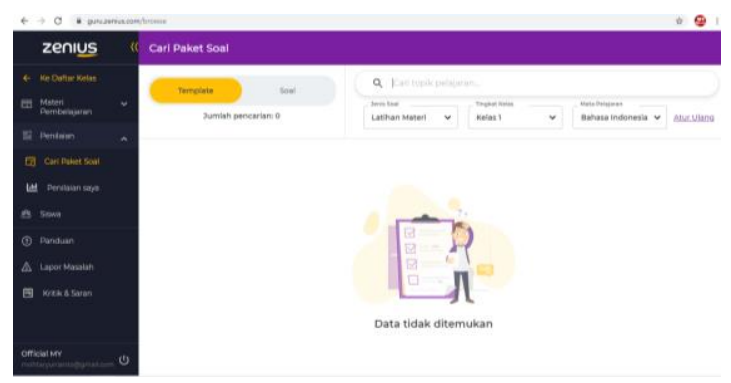

(a)

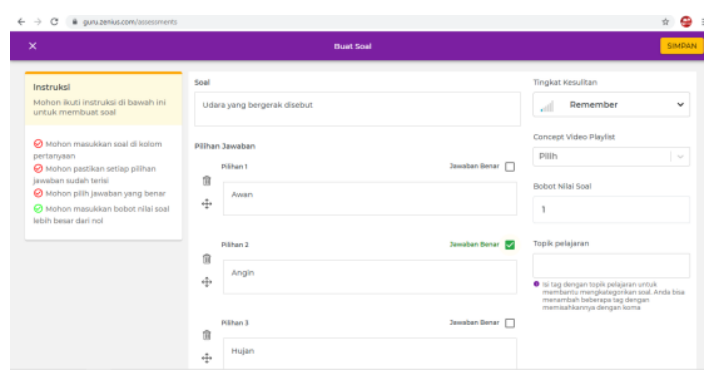

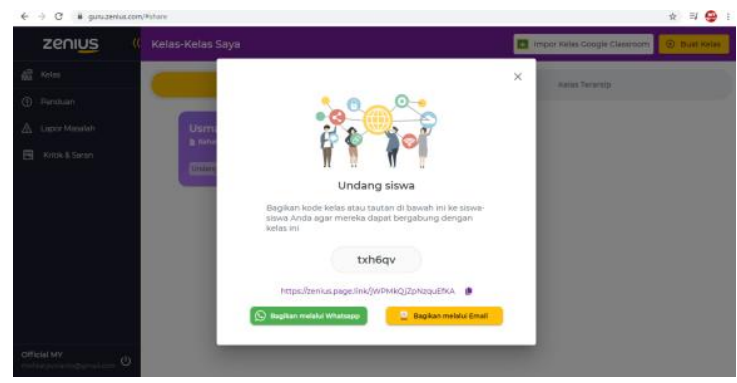

(b)

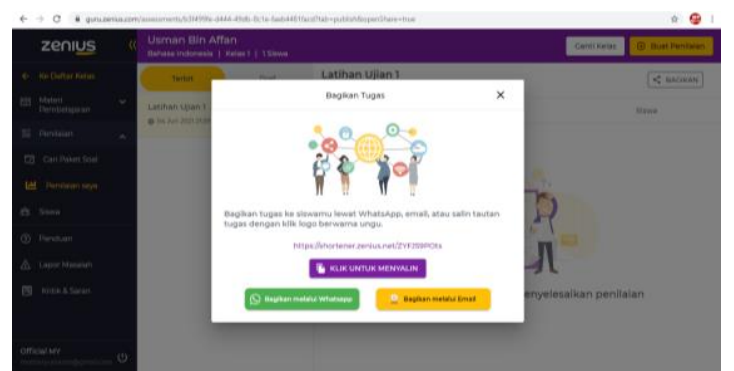

Gambar 3(a). Tampilan menu untuk halaman Guru dan (b). Tampilan untuk mengundang siswa agar bergabung dalam kelas yang dibuat Guru (c). Tampilan membuat soal (d). Tampilan membagikan soal ke siswa.

Tahap selanjutnya adalah mengenalkan aplikasi zenius melalui handphone, diawali dengan menginstal aplikasi melalui playstore ( Gambar 4 ) dan login menggunakan alamat email, setelah masuk ke aplikasi ditampilan menu kelas yang aktif dan apabila sudah joint di kelas dapat melakukan aktivitas seperti mengakses materi pembelajaran maupun pengerjaan soal ujian seperti pada Gambar 5.

\section{Zenius - Belajar \\ Online Seru | UTBK, UM, PTS, \\ PAS \\ PT Zona Edukasi Nusantara}

Gambar 4. Tampilan Aplikasi zenius di playstore
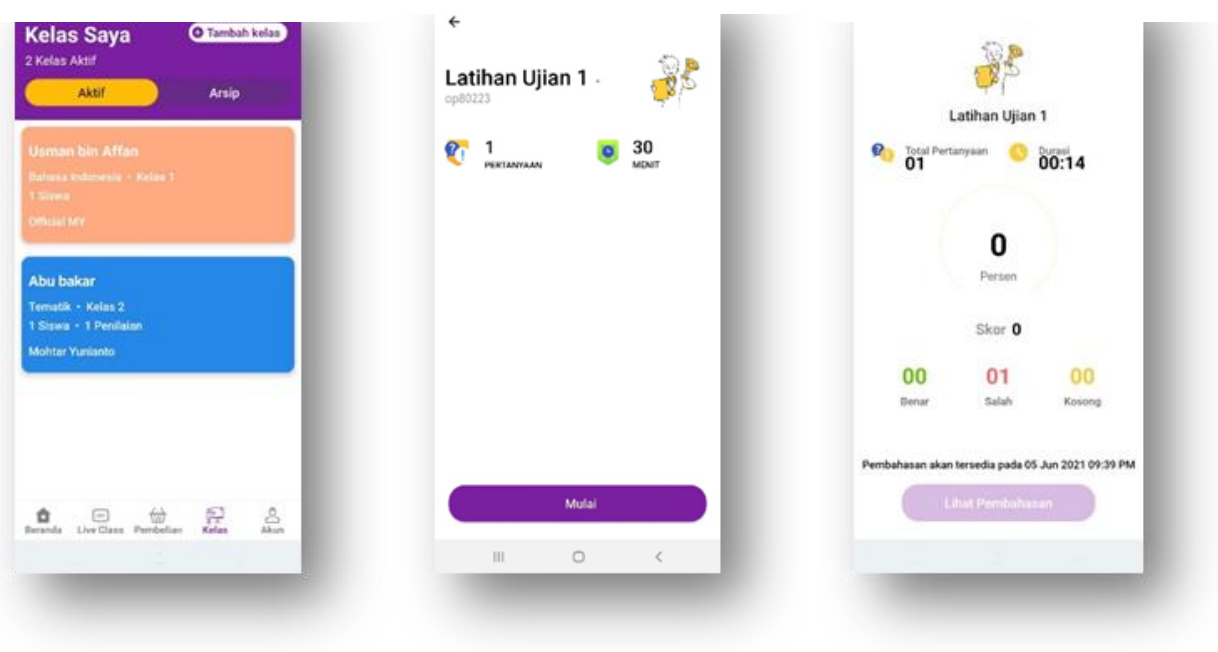

Gambar 5. Tampilan aplikasi zenius dalam handphone 
Dalam kegiatan pelatihan pemanfaatan zenius, peserta yang terdiri dari 17 Guru SD Muhammadiyah Wonorejo sangat antusias mengikuti dari awal sampai akhir, diskusi interaktif terbangun dengan baik karena peserta yang mengikuti sebagian besar belum memahami aplikasi pembelajaran online dan bersemangat untuk dapat memahaminya, proses pelatihan dengan pemateri dari UNS tersaji pada Gambar 6
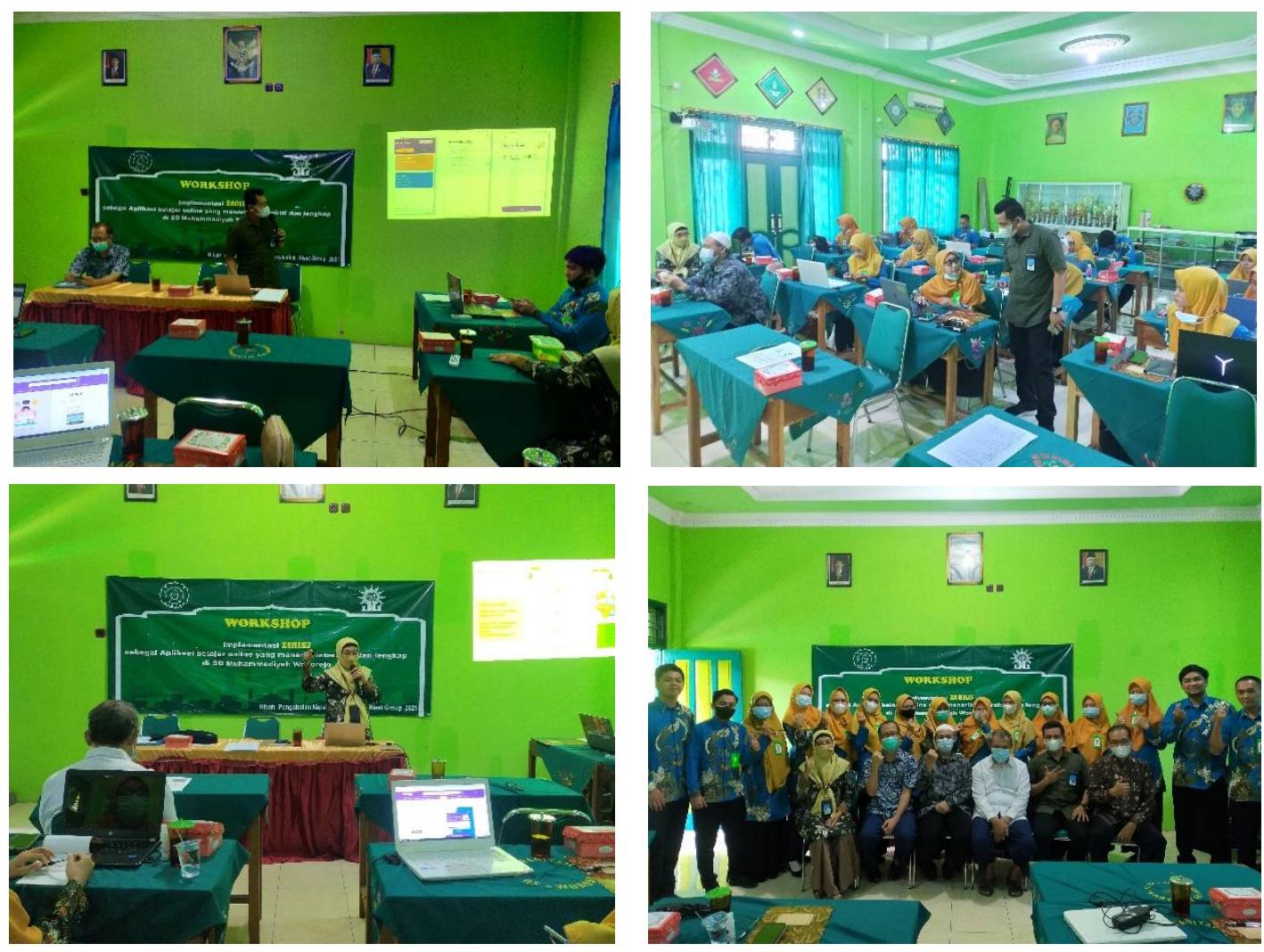

Gambar 6. Kegiatan Pelatihan dan foto bersama Peserta Pelatihan

Setelah dilakukan pelatihan, dalam rangka mengetahui dan mengukur keberhasilan kegiatan, dilakukan pengisian kuesioner dengan hasil pada Tabel 2, diperoleh hasil semua peserta mengenal Aplikasi Pembelajaran online dan akan menggunakan dalam pembelajaran karena mudah digunakan, gratis dan user friedly meskipun ada kendala utama yang dihadapi yaitu masalah koneksi internet.

Tabel 2. Hasil quesioner setelah pelatihan

\begin{tabular}{clc}
\hline No & \multicolumn{1}{c}{ Uraian } & Prosentase \\
\hline 1 & Mengenal Aplikasi Pembelajaran online & $100 \%$ \\
2 & Akan menggunakan untuk pembelajaran & $100 \%$ \\
3 & Apakah pelatihan ini bermanfaat & $100 \%$ \\
4 & Kendala Internet & $47 \%$ \\
5 & Mudah digunakan & $100 \%$ \\
\hline
\end{tabular}

\section{Kesimpulan}

Telah dilakukan kegiatan dalam rangka implementasi Aplikasi Pembelajaran online zenius bagi Guru SD Muhammadiyah Wonorejo, sebelum dilakukan pelatihan hanya berkisar $29 \%$ yang mengetahui Aplikasi pembelajaran online, setelah kegiatan pelatihan semua peserta dapat memahami dan akan menggunakannya dalam 
pembelajaran. Dalam pelatihan tersebut dikenalkan Aplikasi zenius berikut semua menu yang ada baik menggunakan browser di laptop maupun aplikasi di handphone.

\section{Ucapan Terima kasih}

Penulis mengucapkan terima kasih kepada Lembaga Penelitian dan Pengabdian kepada Masyarakat Univeristas Sebelas Maret Surakarta yang telah mendanai kegiatan ini melalui Skema Pengabdian kepada Masyarakat Hibah Grup Riset melalui dana non APBN dengan nomer kontrak 261/UN27.22/HK.07.00/2021 dan juga Kepala Sekolah Dasar Muhammadiyah Wonorejo Kecamatan Polokarto atas ijin dan kerjasamanya sehingga kegiatan ini dapat terselenggara dengan baik.

\section{Daftar Pustaka}

Anugrahana, A. (2020). Hambatan, Solusi dan Harapan: Pembelajaran Daring Selama Masa Pandemi Covid-19 Oleh Guru Sekolah Dasar. Scholaria: Jurnal Pendidikan dan Kebudayaan, 10(3), 282-289.

Kemendikbud (2020) https://www.kemdikbud.go.id/main/blog/2020/11/pemerintah-daerah-diberikan-kewenanganpenuh-tentukan-izin-pembelajaran-tatap-muka dikases pada 18 Desmener 2020 Jam 21.34

Santoso, D. H., \& Santosa, A. (2020). Covid-19 Dalam Ragam Tinjauan Perspektif. LPPM Mercubuana.

Astini, N. K. S. (2020). Pemanfaatan teknologi informasi dalam pembelajaran tingkat sekolah dasar pada masa pandemi covid-19. Lampuhyang, 11(2), 13-25.

Hadisi, L., \& Muna, W. (2015). Pengelolaan teknologi informasi dalam menciptakan model inovasi pembelajaran (e-learning). Al-Ta'dib, 8(1), 117-140.

Zenius (2020), https://www.zenius.net/

Infokomputer ( 2020), https://infokomputer.grid.id/read/122098990/rekomendasi-lima-aplikasi-untuk-belajaronline-secara-gratis diakses pada 18 Desember 2020 jam 21.56 